\title{
3-Beta-Hydroxysteroid Dehydrogenase Deficiency
}

National Cancer Institute

\section{Source}

National Cancer Institute. 3-Beta-Hydroxysteroid Dehydrogenase Deficiency. NCI

Thesaurus. Code C131088.

Cong enital adrenal hyperplasia due to presumed mutation(s) in the HSD3B2 gene, which results in decreased activity of the enzyme 3-beta-hydroxysteroid dehydrogenase. The clinical manifestations of the deficiency are dependent on the deg ree of reduction in enzymatic activity: $46, X Y$ infants may have incomplete development of the genitalia, while $46, X X$ infants may have virilization. 